\title{
Remittances to Ghana: Benefits to the Housing Sector and Impact of Financial Crisis
}

\author{
Noah Kofi Karley \\ Institute for Housing, Urban and Real Estate Research, School of the Built Environment, Heriot Watt University, Edinburgh, EH14 \\ $4 A S$, Scotland, UK
}

\begin{abstract}
The role of inflow of overseas remittances towards the development of housing sector in Ghana, and the impact of recent financial crisis on the development process is investigated. This is achieved through a review and analysis of information gathered through national and international statistical sources and targeted household and institutional interviews. As a prelude to the analysis the study assessed the importance of remittance as large and growing part of the economic underpinning of developing countries. It then assesses whether remittances have a particular relationship with housing. The research provided an estimate of the nature, level and uses of remittances and the different cyclical characters of other flows. It reveals that the successful real estate market development across Ghana during the past decade benefited from a buoyant national economy, improved financial systems and family remittances. However, the picture changed especially during 2008 attributed mainly to the global financial crisis and economic downturn. The reverberating problems of unemployment and high levels of bankruptcies in the advanced countries were felt but not as pronounced as they were in the major industrialised economies. The discussions concluded by posing a much broader question in relation to other developing countries about how remittances could be mobilised towards the development of the housing sector.
\end{abstract}

Key words: Migrant remittances, housing sector, financial crisis.

\section{Introduction}

The Ghanaian economy, like other developing countries depends highly on external financial support. In particular, family remittances play a big part in the economy. The World Bank estimates that total recorded flows of remittances to developing countries reached US\$167 billion in 2005 [1]. Officially recorded remittance flows to developing countries reached US\$316 billion in 2009 down 6 percent from US\$336 billion in 2008. With improved prospects for the global economy, remittance flows to developing countries were expected to increase by 6.2 percent in 2010 and 7.1 percent in 2011 [2]. These are staggering sums that dwarfs other financial sources, such as official development assistance, bank lending and private investment into developing countries, suggesting that remittances make a powerful

Corresponding author: Noah Kofi Karley, PhD, lecturer, research fields: urban real estate management. E-mail: n.k.karley@hw.ac.uk. contribution to reducing vulnerability at least at the household and local community levels. However, the reverberating problems of unemployment and high levels of bankruptcies in the advanced countries owing to the global financial crisis cannot be overemphasised. One area that could suffer the direct consequences of high levels of unemployment, mortgage foreclosure and banking crisis is inward remittances into these countries. This was concurred by Zoellick [3] who noted that Ghana like other developing countries was likely to experience a drop in trade, capital flows, remittances, domestic investment, as well as a slowdown in growth.

Despite the importance of remittances as outlined above, and their likely impact on welfare (including housing), this relationship has not been sufficiently investigated in Ghana. Thus, the primary aim of this study is to try to fill the knowledge gap by specifically examining how remittance flows can help to improve the housing and home ownership aspiration of 
households in Ghana. To fulfil this aim the primary objective is to understand the nature, motivation and level of migrant remittances to Ghana and how these are remitted. The secondary objective is to ascertain whether the recent financial crisis had any impact on remittances and thus the housing industry in Ghana. The argument for the secondary objective is that households that receive remittances are able to withstand economic shocks since these inflows serve as a form of "insurance" against income shortfalls. Thus, the financial crisis can affect the real estate industry in Ghana where over two-third of customers of private residential property developers are thought to be funded through migrant remittances [4].

As a prelude to the analysis, a systematic literature review is carried out comprising an update of academic literature on understanding, motivation as well as impact of remittances. This is followed by analysis of official statistics on remittances flows and channels by which they are remitted. Analysis of household data and institutional interviews is then undertaken. Finally, the impact of recent financial crisis on remittances is assessed and conclusions drawn.

\section{The Study Approach}

In order to understand the contributions of remittances to the housing sector in Ghana this research investigates several questions: What are remittances? How are remittances distributed? What channels are used to remit these funds? How are remittances spent? Finally, what are the policy implications on housing sector development of how the money is remitted and used, and effects of the recent financial crisis?

In the process of answering these questions this study employed a variety of methods, predominantly desk-based. First, a systematic literature review is carried out comprising an update of academic literature and official statistics on remittances flows. A review and analysis of official statistical information about remittances to Ghana, particularly as collected by statistical service authority and various industry participants is also undertaken. An important source is statistics held by the Bank of Ghana on inward remittances.

For diversity, it is deemed valuable to undertake a number of interviews with households. This study therefore used interviews with targeted Ghanaian residents in the UK to ascertain motivation, use and impact of migrant remittances on housing sector development in Ghana. The interviews explored experiences with remittances and impact of the recent global financial crisis on remittance flow and thus contribution to the housing industry. Discussions with stakeholder institutions such as developer companies, banks and other home loan companies were also undertaken.

\section{The Study Context: A Literature Review}

There has been much successful real estate market development across Ghana during the past decade as many urban areas benefited from buoyant national economy, improved financial systems, high level of Foreign Direct Investment (FDI) and family remittances from Ghanaians living and working abroad [5]. Available data are sketchy because of the high levels of informal sector participation. But analysts and observers [6, 7] agree that the real estate industry has experienced tremendous growth over the past decade. Figures for the past five years and particularly 2007 showed impressive residential property development and activities [4], benefiting from, among others migrant remittances from abroad. Karley [4] estimated that 65 percent of the clients of private residential property developers in Ghana are Ghanaians living and working abroad.

But the picture has been changing especially after the last quarter of 2007 attributable to the global credit crunch and economic downturn. For example, evidence shows that the construction orders of NTHC Properties, one of the main private residential property developers in Ghana declined by about 15 per cent in 2008 after a constant growth for 5 years [8] although this has started 
to show signs of growth again from 2010. The Ghana Real Estate Developers Association [9] also indicated that 2009 and beyond have been tough for its members as they experienced unfulfilled stage payments for houses completed.

\subsection{Understanding Remittances and Motivation for Them}

The term "remittances" can be seen from different perspectives. In simple terms it refers to the money that migrant workers send back to their communities or home countries of origin. Addison [10] views remittances as financial flows into households that do not require a quid pro quo in economic value. Although they can also be sent in kind, the term "remittances" is usually limited and referred to monetary and other cash transfers transmitted by migrant workers to their families and communities back home. While the motive behind remittances may not be for a direct compensation in return, literature on remittances as discussed later confirms elements of quid pro quo behind transfers although these may not be immediate or binding.

A large population of Ghanaians live outside Ghana, and their contribution to the Ghanaian economy and to individual households cannot be overemphasised. Remittances are an integral feature of many developing countries. As migration continues to increase, the corresponding growth of remittances has come to constitute a critical flow of foreign currency in many developing countries and Africa in particular. The literature on remittances give several and diverse explanations to motivation for it. These motivations are summarised by Solimano [11, 12] as: (1) altruism motive, (2) self-interest motive, (3) implicit family contract I: Loan repayment and (4) Implicit family contract II: Co-insurance.

The altruistic and self-interest models explained the remittances process from the individual perspective. The altruism motive also referred to as livelihoods school of thought considers remitting as an obligation to the household. It argues that remittances are sent out of affection and responsibility towards the family and sending remittances yields a satisfaction to the migrant out of a concern for the welfare of family [13]. The Self-Interest Motive assumes that the migrant is mainly motivated by an economic and financial self-interest. The argument is that the aim of a successful migrant is to save as much money as possible whiles they are in a foreign country in order to be able to invest back in their home country by buying property, land, financial asserts, and so on. In turn, the family can administer, during the emigration period, those assets for the migrant, thus acting as a trusted agent. Although these assets may earn a higher rate of return than assets in the host country, for various reasons their risk profile can also be greater.

The literature has also considered the discussion on the remittance process from the family perspective rather than the individual. According to the implicit family contract I (Loan repayment) model, families tend to develop an implicit contract among those who choose to live abroad, the migrant, and those who stay at home. The family invests in sponsoring a family member to travel abroad for study or directly for greener pastures with the hope that when they have settled well and start earning the migrant will be able to pay back to the family by remitting. This implicitly implies that the family invests in a higher yield asset (migrant). However, the amount to be remitted depends among other things, on the income profile of the migrants and conditions in the foreign country.

The implicit family contract II (Co-insurance) theory argues that remittances occur largely because migration forms part of a strategy for "livelihood diversification”. In countries where agricultural activities are predominant forms of economic activities, the sector is unable to employ the growing population. Therefore, in order to minimise their risks and raise their returns to available labour in the family, households spread their earning activities over a range of activities including sponsoring family member 
(often most educated) to migrate. The migrant, then, can help to support his family in bad time at home and they in turn can help the migrant in bad times in the foreign country. Migration becomes a co-insurance strategy with remittances playing the role of an insurance claim. It is observed in this model that family trust and altruism helps in minimising potential problems usually associated with the contract, a feature often absent in legally sanctioned contracts.

\subsection{Impact of Remittance Flow}

There has been a growing literature examining how migrant workers' remittances can affect households. Among these studies, some have documented how migrants have contributed to economic and social development in their country of origin. Evidence suggests that remittances from abroad are crucial to the survival of communities in many developing countries as indicated in a World Bank Country Analyses report by Russell et al. [14]. One benefit expected from labour emigration was that migrants would be bringing an impetus to investments, transfer of technology and machinery and new enterprises. Thus, Russell et al. [14] concluded that after satisfying subsistence needs, migrant remittances are used for investment purposes such as education, livestock, farming, and small scale enterprise. Taylor [15] has also argued that remittances have multiplier effects that work to increase national income. In a study on Senegal, Diatta and Mbow [16] found that remittances were a substantial source of revenue for families with migrant members and were also used to promote development in migrants' home communities.

Study by Koc and Onan [17] shows that remittances significantly affect welfare. They examined the impact of remittances on the standard of living of families of emigrants in Turkey and found that remittances have a positive effect on household welfare. Their study shows that remittances have both direct and indirect income effects, which potentially have important influences on production, income inequality and poverty, at least at the local level. They found that 12 per cent of households used about 80 per cent of remittances to improve their standard of living, although it is argued that dependency on the same leaves households vulnerable to changes in migration cycles.

Migrant remittances also serve as a source of income for savings and investment, as confirmed by Taylor [15], and thereby lead to growth and development of an economy. This is corroborated in a study on Mali by Findley and Sow [18], who report that remittances not only covered basic food and cash needs but also allowed people to pay for irrigation in agriculture. Research in Somaliland has highlighted investment of remittances in production even in highly unfavourable economic and political conditions [19]. Similarly, Kannan and Hari's [20] study of the macroeconomic impacts of remittance flows in India indicates that remittances have made significant impact on savings.

The importance of remittances has also been examined empirically in terms of its impact on poverty. Adams and Page [21], using data from 74 low- and middle-income developing countries, found that international migration has a strong statistical impact on reducing poverty: On average, a 10 percent increase in the share of international migrants in a country's population will lead to a 1.9 percent decline in the share of people living in poverty. Thus, international remittances strongly affect poverty and they tend to minimize the negative effects of economic shocks in an economy.

Contribution of remittances to households in developing countries cannot be overemphasised. Analysis of household surveys shows that remittances have been associated with significant declines in poverty (headcounts) in several low income countries, including Uganda (11 percent), Bangladesh (6 percent) and Ghana (5 percent). Unlike development assistance transfers which mostly pay for the expensive lifestyles of NGO executives and lines the pockets of corrupt 
politicians, migrant remittances go directly to family members. They tend to increase at difficult times during an economic downturn when other private capital flows tend to decrease.

Migration and Development Brief [2] also indicated that migrant remittances are increasingly becoming more constant sources of income to most developing countries with a doubling of annual remittances in most countries. Further, unlike foreign investment, remittance flows are more evenly distributed and far more stable. Sander [22] observed that remittances have proved to be the most stable flow compared with ODA and private capital flows. This assertion is consistent with data from the World Bank Migration \& Remittances Team [2] showing that unlike private capital flows which declined sharply during the recent financial crisis remittance flows have remained resilient and have become even more important as a source of external financing in many developing countries.

With respect to Ghana, dated back to the late 1960s, Caldwell [23] investigated the uses of remittances from internal migration in Ghana and found that migrants spent remittances to pay for schooling and wages of farm labourers, and to develop small businesses. Also, a survey conducted by the Sussex Centre for Migration Research in Ghana, particularly in the Ashanti Region in March 2003, identifies three main uses of the remittances. First, remittances are used to satisfy individual needs such as smoothing consumption needs, organizing funerals and meeting other pressing social needs. The second motive is to support social projects in migrants' originating communities. The third motive, less common but perhaps the most important for the promotion of economic development, is for productive investments. Under this third category, the most common objective is for migrants to invest in businesses of their relatives in their home country.

Litchfield and Waddington [24] also examined the welfare outcomes of migrants and non-migrants in
Ghana using Ghana Living Standards Survey (GLSS) data. They found that migrant households have statistically significantly higher living standards than nonmigrants, although there appears to have been a slight decline in the extent of migration over the decade. A recent study on remittances of Ghanaian emigrants in Sydney, Australia [25] also shows that by saving about a third of their incomes, emigrants are able to build houses in their home country Ghana within 3-6 years.

The Bank of Ghana (BoG) also highlighted the significant contributions to national development by remittances from the over one million Ghanaians living and working abroad. In the early 1980s during the period of economic downturn in Ghana, remittances helped the Ghanaian economy greatly, influencing economic policies positively and straightening the economic fundamentals in the economic structural adjustment programme [26]. Addison [10] noted that private transfers to Ghana are much bigger and more stable than Official Development Assistance (ODA) and FDI over the period 1990-2003. Year-on-year figures show a steady rise, with conservative figures showing a more than 25 percent increase in remittance flows since the later parts of 2006 [5]. Also, remittances have been increasing more than proportionately compared to GDP and export earnings.

In conclusion, the empirical literature suggests that remittances make a powerful contribution to reducing vulnerability at least at the household and local community levels.

\section{Distribution of Remittances}

Remittances by migrants have become an important source of income and foreign exchange for many developing countries. Remittance flow globally currently exceeds US\$300 billion, which is greater than the value of official development assistance (ODA). Remittances to developing countries amount to some US\$335 billion (Sub Sahara Africa, US\$21.6 billion) in 2010 [2]. Sander [22] notes that remittance flows 
have concentrated in a group of developing countries. In 2002, Latin America and the Caribbean had the highest level of remittances, totalling US\$25 billion, followed by South Asia with US\$16 billion and the Middle East and North Africa with US\$14 billion. Sub-Sahara Africa had the lowest level of remittances, amounting to US\$4 billion (with an annual growth rate of 5.2 percent). The corresponding figures and outlook for remittances flows for 2009-2011 indicates a similar trend but quite a big jump in the amounts involved as shown in Table 1.
The distribution of remittances to the top recipient developing countries in terms of the share of remittances in GDP in 2008 (Fig. 1, expressed in 2008 terms) shows that in these economies remittances exceeded a quarter of the GDP. Data on remittance flows to Sub-Sahara Africa are sparse, but these flows appear to have declined only modestly in 2009 as shown in Table 1. Arguable this provides a lifeline to the poor in developing countries.

Table 1 Outlook for remittances flows for 2008-2011 [2].

\begin{tabular}{|c|cccc|}
\hline US\$ billion & 2008 & 2009 & $2010 \mathrm{f}$ & $2011^{*}$ \\
\hline Developing countries & 335.8 & 315.7 & 335.4 & 359.1 \\
East Asia and Pacific & 86.1 & 85.7 & 94.1 & 102.7 \\
Europe and Central Asia & 57.5 & 45.6 & 48.1 & 51.7 \\
Latin America and Caribbean & 64.4 & 56.5 & 559.8 & 64.5 \\
Middle-East and North Africa & 34.8 & 32 & 33.1 & 34.5 \\
South Asia & 71.7 & 75.2 & 78.7 & 82.8 \\
Sub-Saharan Africa & 21.3 & 20.7 & 21.6 & 22.9 \\
Droweloping countries & $15.90 \%$ & $-6.20 \%$ & & \\
East Asia and Pacific & $20.70 \%$ & $-0.40 \%$ & $9.20 \%$ & $7.10 \%$ \\
Europe and Central Asia & $13.30 \%$ & $-20.70 \%$ & $5.40 \%$ & $9.20 \%$ \\
Latin America and Caribbean & $2.10 \%$ & $-12.30 \%$ & $5.70 \%$ & $7.60 \%$ \\
Middle-East and North Africa & $9.80 \%$ & $-8.10 \%$ & $3.60 \%$ & $7.90 \%$ \\
South Asia & $32.60 \%$ & $4.90 \%$ & $4.00 \%$ \\
Sub-Saharan Africa & $14.10 \%$ & $-2.70 \%$ & $5.40 \%$ & $5.20 \%$ \\
\hline
\end{tabular}

*Estimated.

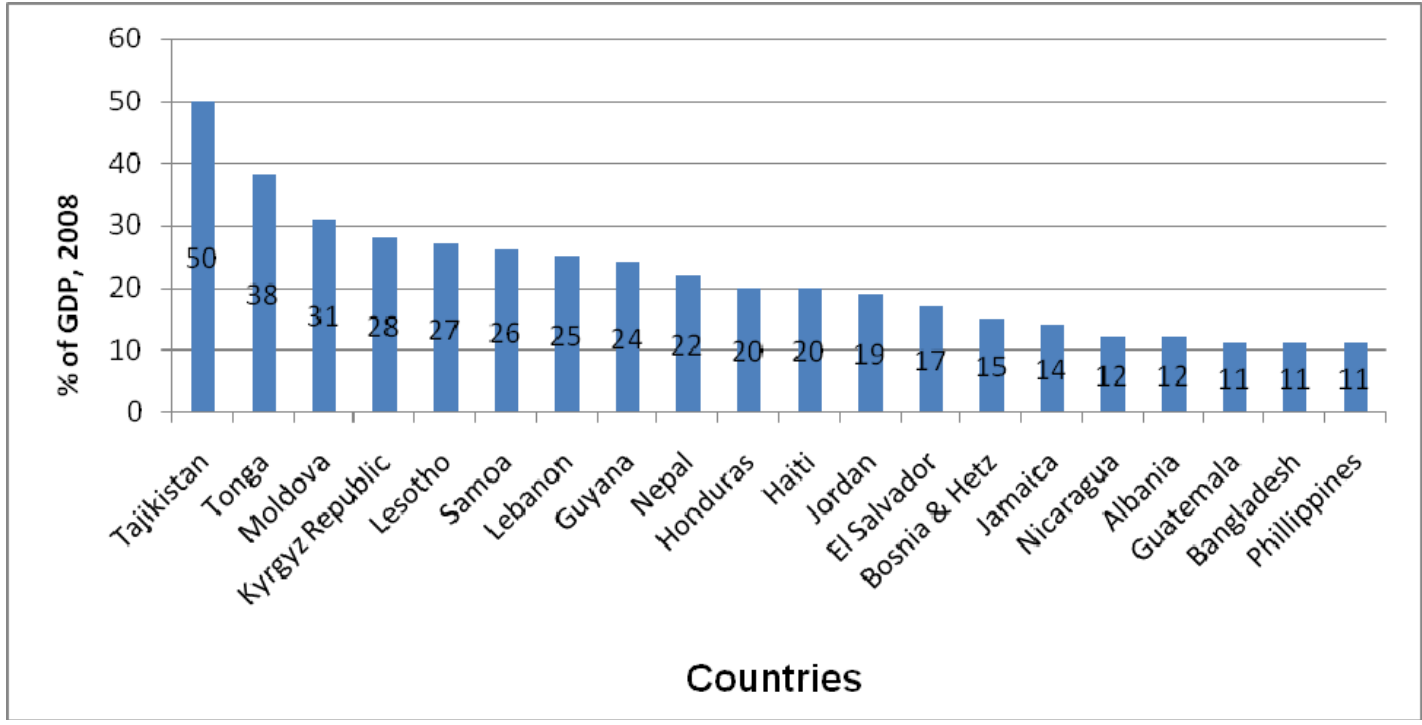

Fig. 1 Top 20 remittance recipients in Developing Countries, 2008 [2]. 


\section{Volume of Remittances to Ghana}

The importance of remittances as a source of foreign exchange is widely acknowledged in Ghana but there is less agreement on the volume of remittance flows coming into the country. According to the BOPs data portrayed in Fig. 2a, total transfers to the Ghanaian economy ranged between US $\$ 400$ million in 1990 and US\$935 million in 2001. Of the total transfers, private unrequited transfers increased from US\$201.9 million to almost US\$718 million in 2001. Over the years private unrequited transfer has gained significant importance in total unrequited transfers. In Fig. 2a, while private unrequited transfer jumped up strongly between 2002 and 2005 (from US\$1.1 billion to US\$3.8 billion), official transfer rather followed a relatively sluggish upward trend during the same period. Recent estimates in Fig. $2 \mathrm{~b}$ show a strong increase in private transfer in 2006 from US $\$ 4.7$ billion to US\$9.68 billion in 2010, which represents 27.8 percent increase over those for the corresponding period in 2009.

Whiles total private transfers have been increasing, transfers to individuals peaked in 2008 at US\$13.6 billion and have since been descending as shown in Fig. 3a. The corresponding decrease in share of individual transfers as percentage of private transfers portrayed in Fig. 3b continued to decline and down from 36.5 percent in 2005 to 14.1 percent in 2010. This could largely be attributed to the recent financial crisis started around end of 2007.

\section{Channels and Uses of Remittances}

In principle, remittances inflow can be measured in one of three ways. The first approach is the balance of payments estimates, second is micro or household surveys of recipients of such flows, and the third method is through banks or financial institutions in origin countries. The Bank of Ghana is one of the few national banks in Africa to collect statistics on remittances, which it requires from registered banks and transfer agencies. The estimates of formal remittances made by the Bank of Ghana are higher than those given in the IMF's Balance of Payments (BoP) statistics and the World Bank's Global Development Report (which uses statistics derived from the BoP data). Private, Official and Total Unrequited Transfers to Ghana between 1990 and 2005 were shown in Fig. 2a, and Fig. 2b shows private Inward Transfers through Banks from 1990 to 2010.

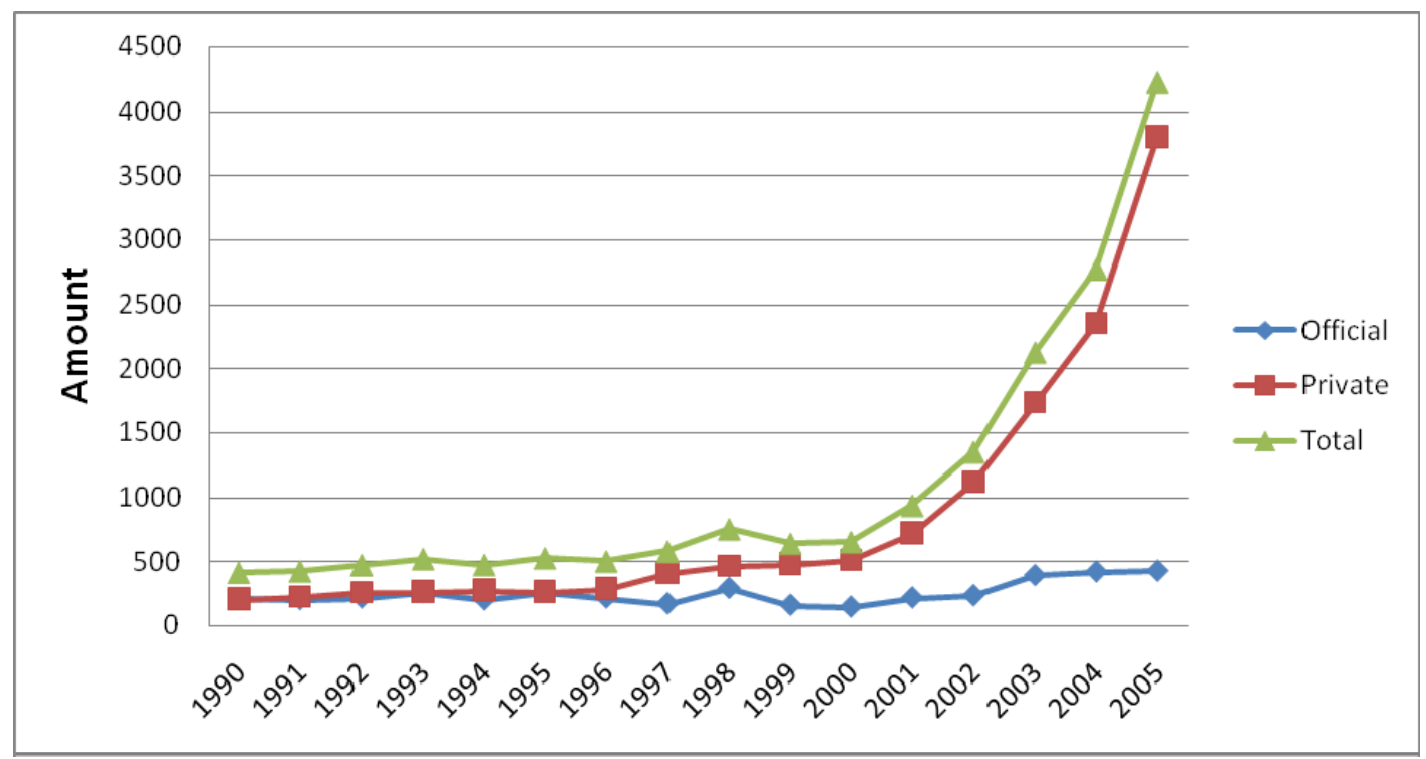

Fig. 2a Private, official and total unrequited transfers (US\$ million) (1990-2005).

Sources (Fig. 2b): Data for 1990 to 2001 derived from Bank of Ghana BOP office and 2002 to 2010 from BOG Monetary Policy Report Vol. 4 No.5 (2010). 


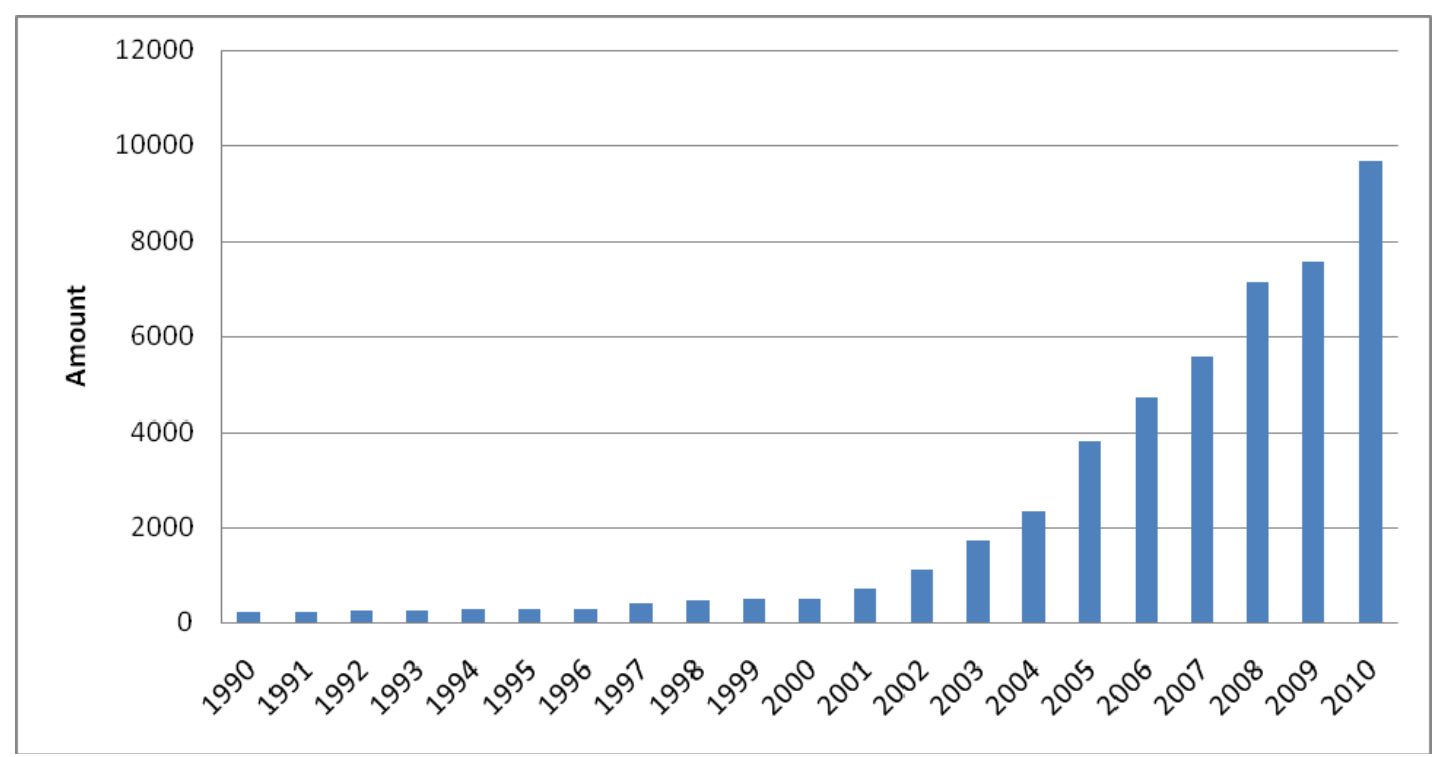

Fig. 2b Private transfers (US\$ million) 1990-2011.

Sources (Figure 2a): Data for 1990 to 2001 derived from Bank of Ghana BOP office and 2002 to 2010 from BOG Monetary Policy Report Vol. 4 No.5 (2010).

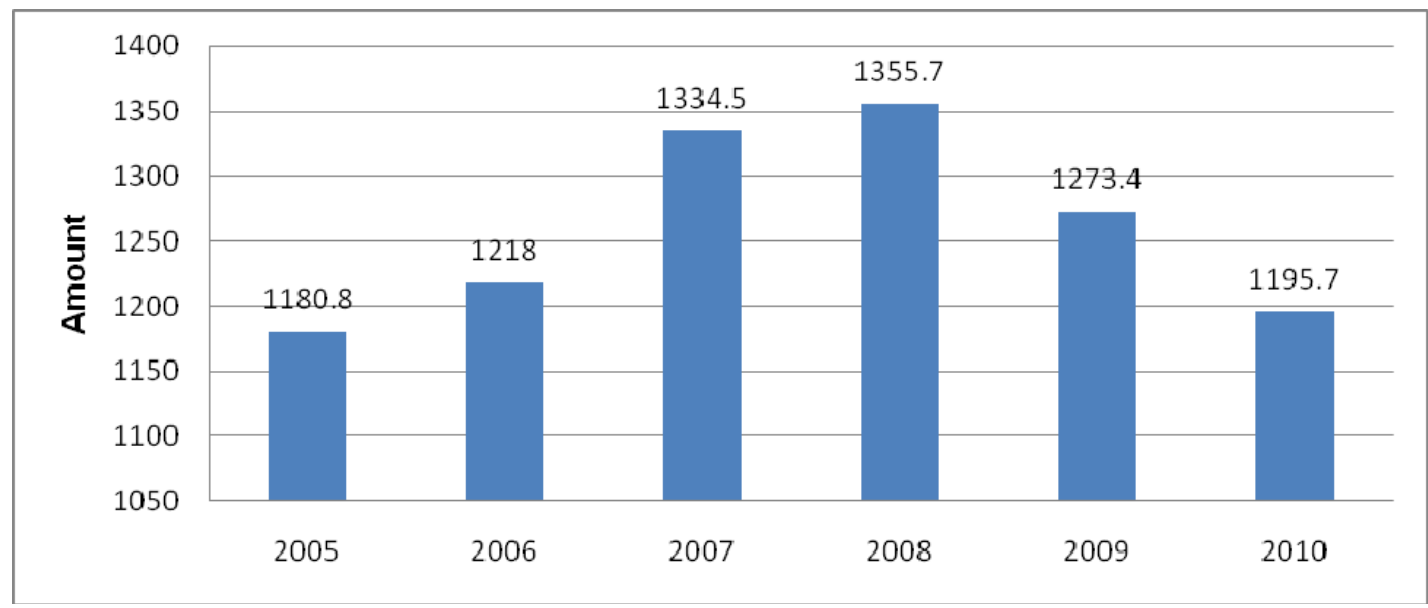

Fig. 3a Transfers to individuals in US\$ millions (2005-2010).

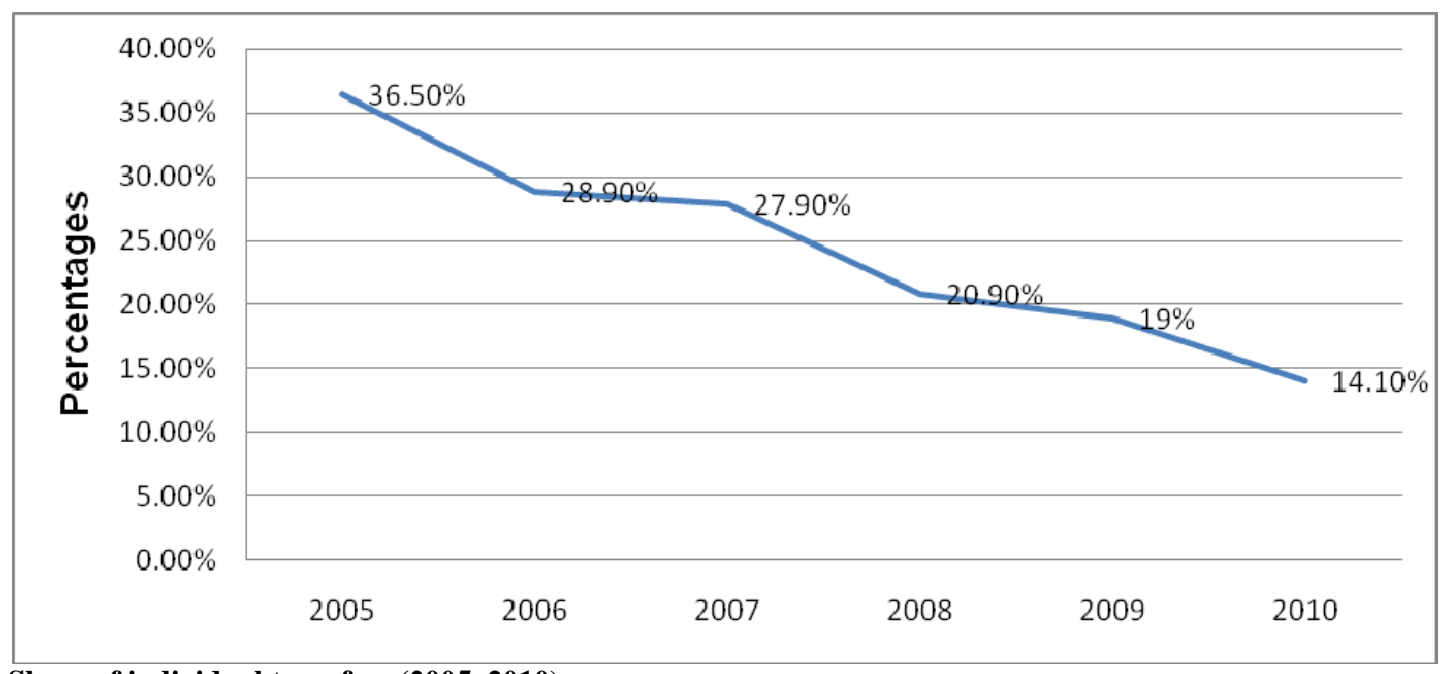

Fig. 3b Share of individual transfers (2005-2010).

Sources (Figs. 3a-3b): Data derived from Bank of Ghana Monetary Policy Report Vol. 4 No.5 (2010). 
However, none of these data sets take into account informal remittance flows, which are likely to be substantial. The fact that remittances are transmitted through different channels makes it difficult to capture the full amount in the balance of payment statistics of the recipient country, which tends to underestimate the actual flow of remittances. This problem makes it difficult to come up with strong conclusions on the role remittances play in the economy. Also, without detailed records of household budgets it is difficult to gauge exactly how remittances are allocated, or the role of remittances in freeing up alternative sources of household income for different kinds of usage.

It has not been possible to obtain official data on amount of informal remittances and their uses. So in order to establish how these funds are transmitted and used, data based on interviews, personal observation and other records are explored. In all, 200 Ghanaian migrants based in different regions in the UK were identified through Ghana High Commission and local church sources. They were asked to complete questionnaire and followed with telephone interviews with 10 selected from the sample. Table 2 shows the distribution of sample and the response rate.

Eighty responses or 40 percent of questionnaire were returned completed, among which 5 respondents indicated they never remitted funds back home since arriving in the UK. The respondents were grouped into two main job categories. Those employed in jobs perceived as skilled are referred to "professionals" in this study; and those unskilled referred to "others". The discussions are based on analysis of findings from the 75 responses received. The questionnaire also sought estimates of income levels, proportions remitted regularly, purpose of remitting, and overall remittance experiences.

\subsection{Methods of Migrant Remittances}

Migrants remit funds formally through bank transfers and formal money operators such as Western Union and Moneygram. Informal remittances tend to be most significant in countries with relatively undeveloped banking sectors and where trade and exchange-rate restrictions encourage parallel markets and foreign exchange rates. The Bank of Ghana sets the official exchange rate by averaging the exchange rates of the licensed banks, which are liberalized and determine their own exchange rates. However, inflation, fluctuations in the value of the Ghana currency, the cedi and general susceptibility to the vagaries of the global market for a narrow range of export commodities lead to Ghana being characterized by high levels of economic uncertainty. This generates some of the conditions necessary for parallel and informal markets for remittance transfers and foreign exchange quite apart from any foreign-exchange regulatory regime.

Table 2 Distribution of questionnaire and response rates.

\begin{tabular}{|c|c|c|c|}
\hline Areas & Target & Returned questionnaire & Response rate (\%) \\
\hline Edinburgh & 20 & 14 & 70 \\
Glasgow & 20 & 9 & 45 \\
Newcastle & 20 & 6 & 30 \\
Manchester & 20 & 9 & 45 \\
Liverpool & 20 & 5 & 35 \\
Birmingham & 20 & 7 & 45 \\
Cambridge/Oxford & 20 & 9 & 35 \\
London & 60 & 21 & 40 \\
\hline Totals & 200 & 80 & \\
\hline
\end{tabular}

Source: Derived from UK-Ghanaian residents survey (2011). 


\subsubsection{Foreign Exchange Bureaus}

Exchange-rate fluctuations and economic uncertainty allow foreign exchange bureaus (usually referred to as forex) to undercut the official exchange rate and benefit from devaluations in the cedi (the Ghana currency) relative to hard currencies. Their competitive rates mean forex bureaus are commonly used for foreign exchange transactions and anecdotal evidence suggests they may also be key players in informal remittance systems in Ghana. They offer better exchange rates than the banks, a main reason for migrants' aversion to banks and use of informal channels. Furthermore, while there are large numbers of licensed forex bureaus in Accra and other cities in Ghana, there are also shops and other small businesses that do not have a forex licence but are involved in unregulated foreign exchange and money transfer activities. Informal transfers are often made from so-called "ethnic stores" in the migrant's country of residence and the money is received at unregulated agencies or forex bureaus in Ghana.

The Fig. 4 shows the distribution of respondents by method they use in transferring remittances to Ghana. It also shows distribution of respondents by the type of work they do and how they transmit remittances. All four methods identified are used by migrants in varying degrees. Money transfer operators and cash are extensively used by all groups of migrants. Courier service and shipment of goods is also heavily used method. If work they do are considered bank transfer is common with professionals compared to "others".

\subsubsection{Money Transfer Operators}

This includes both formal and informal operators. There is a wide variety of informal money transfer operators used by Ghanaian migrants to send remittances. The remittance sending operators, working principally from developed countries, are as much a part of informal remittance systems as their receiving counterparts in Ghana. Migrants often prefer to use the transfer services offered by Ghanaian-owned shops or small businesses in their country of residence than banks or "formal" money transfer operators such as Western Union and Moneygram. But in this study all respondents said they use money transfer operators. This preference may be as a result of the savings made by using informal transfer methods, but it may also be linked to social and cultural ties that encourage Ghanaian migrants to utilize and support the services offered by other Ghanaians.

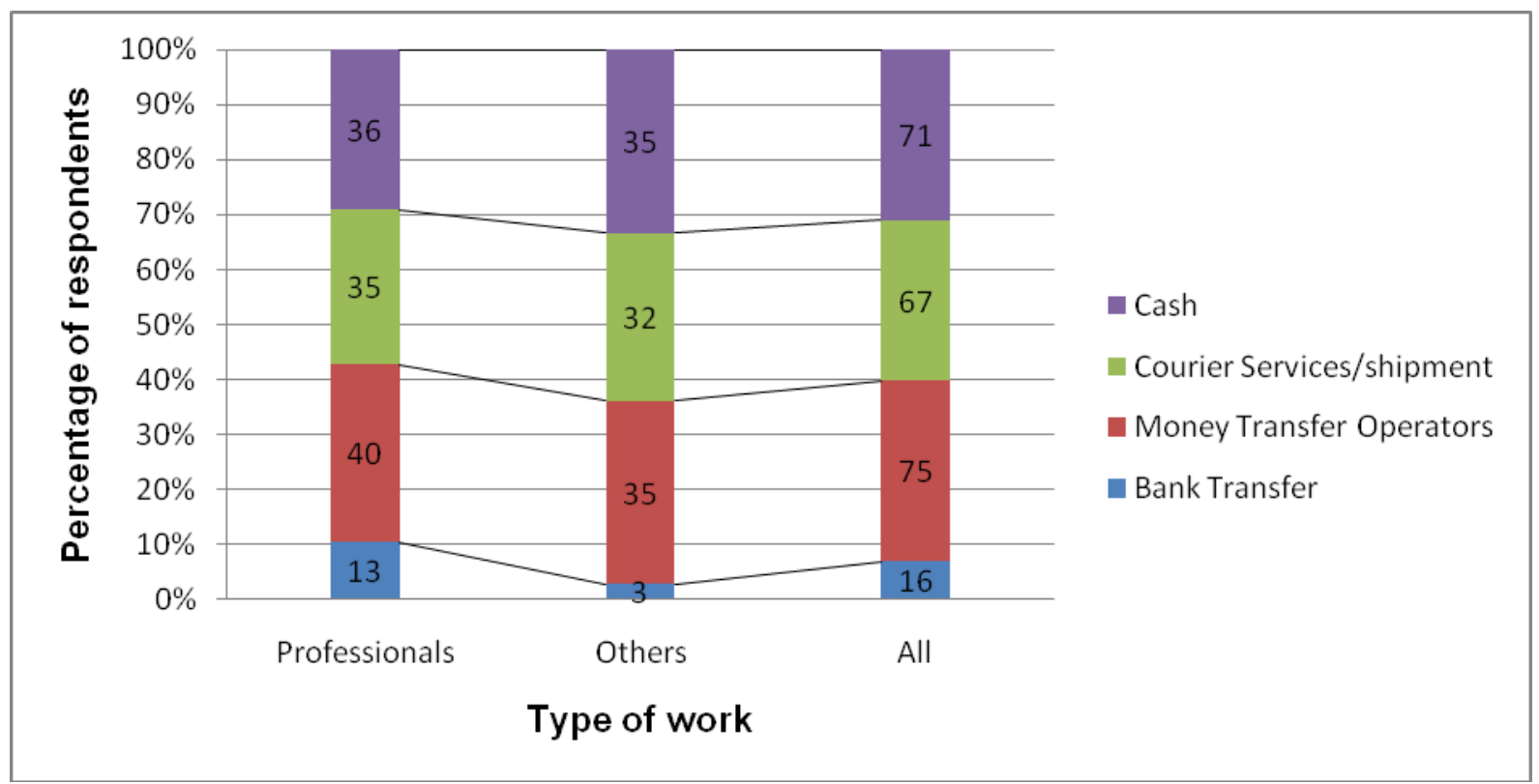

Fig. 4 Methods of migrant remittances.

Source: Derived from UK-Ghanaian residents survey (2011). 


\subsubsection{Courier Services and Cash-in-Hand Transfers}

Money and in-kind transfers are carried by hand to Ghana by returning or visiting migrants and by couriers who offer direct money transfer services as a business. Indications are that Africans in general send a greater proportion of remittances through hand-carrying of cash or kind than other migrant groups [27]. This may also be true for Ghanaian migrants, as shown by this research, 95 percent of respondents use this method. The physical transportation of remittances to Ghana includes money transferred in cash or travellers cheques and goods, usually consumer durables, brought into the country by migrants for their families to use or sell to other people. In 2006 the government announced a proposal to tax part of migrant's remittances to pay for physical and social infrastructure associated with housing development and other type of capital projects used by Ghanaian migrants. This triggered a huge debate and encouraged cash-in-hand transfers. These transfers are very difficult to trace and do not enter official estimates of remittance volumes for Ghana. It seems reasonable to assume that the greater the mobility of migrants, the greater cash-in-hand transfers are likely to be, since this form of transfer depends on making trips back to Ghana.

There is some anecdotal evidence to suggest that Ghanaians lack trust in informal remittance services offered by "ethnic" stores and forex bureaus and prefer couriers and formal channels. However, this is very difficult to substantiate on the basis of existing research. There are indications that certain groups of Ghanaian migrants rely more heavily on informal channels than others, so the degree of trust in informal systems may also depend on the social and economic background of the migrant. Research by Tiemoko [28] suggests that migrants who remit less frequently are more likely to use informal channels. Migrants who send remittances tend do so on a regular basis, but less-skilled migrants were generally found to send remittances more often than élites, and were more likely to remit through formal channels.

\subsection{How Are Remittances Spent?}

The findings on the use of remittances are discussed under two main themes viz., "productive investment" and "consumptive investment". Here, "productive investment" refers to investment in activities that increase the household's capacity to earn money, this include agricultural production, and the establishment of small businesses. "Consumptive investment” refers to goods and services that more immediately improve the wellbeing of the household members, this include house building, house purchase, purchase of consumer goods and the payment of health and education expenses. On average most respondents said a third of their incomes are remitted on regular basis for the allocated purposes.

When asked to indicate their use-preferences, it is observed that a small proportion of respondents (14.7 percent) indicated productive investment as a primary choice, while a vast majority (85.3 percent) is used for consumptive investment such as house building (41.3 percent) (see Fig. 5). This observation is in line with trends in other developing countries as revealed by de Brauw and Rozelle [29].

\subsubsection{Agricultural Investment}

In comparison with other areas of remittance usage, agriculture benefits relatively little from remittances. Out of the total of 75 respondents, only three or 4 percent indicated agricultural as the primary reason and only 2 respondents indicated it as a secondary reason for sending money home (see Fig. 6a). The low rate of return to productive capital investment in agricultural in general perhaps discourages investment in such activities. Some of those who stated agricultural as a primary purpose of remitting alluded to the fact that they already have large farmlands back in their hometowns. So could it be a sign that perhaps insecure land rights may well discourage investment in this activity? A typical comment from those who did not 


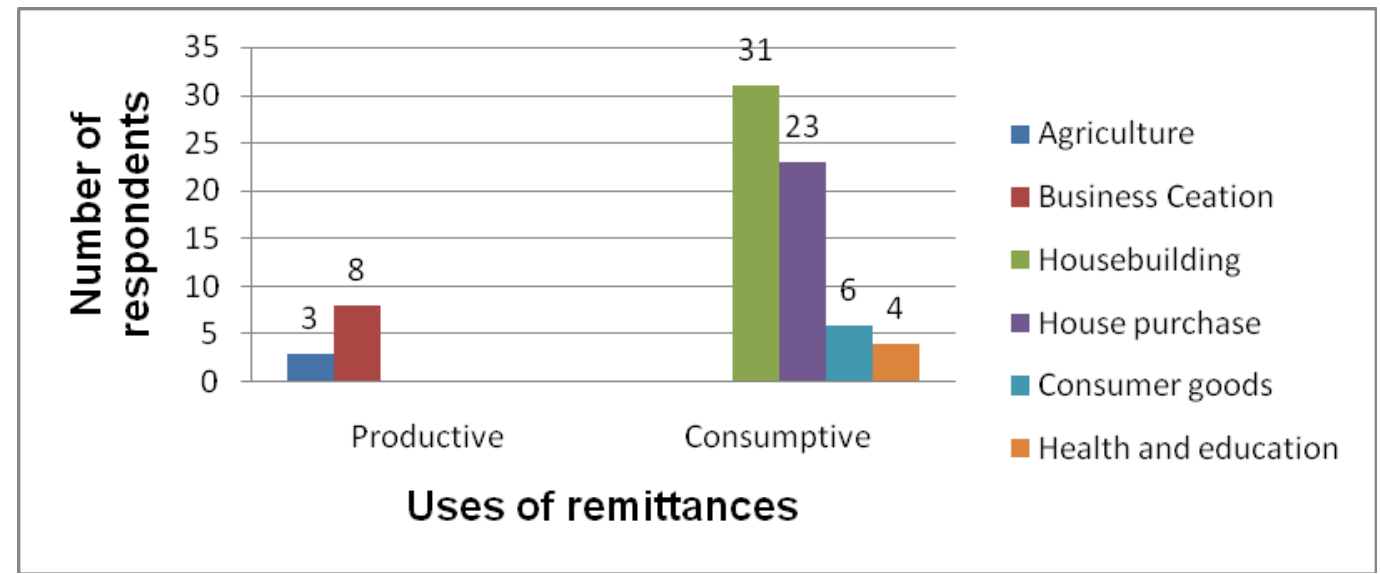

Fig. 5 Productive versus comsumptive uses.

Source: Derived from UK-Ghanaian residents survey (2011).

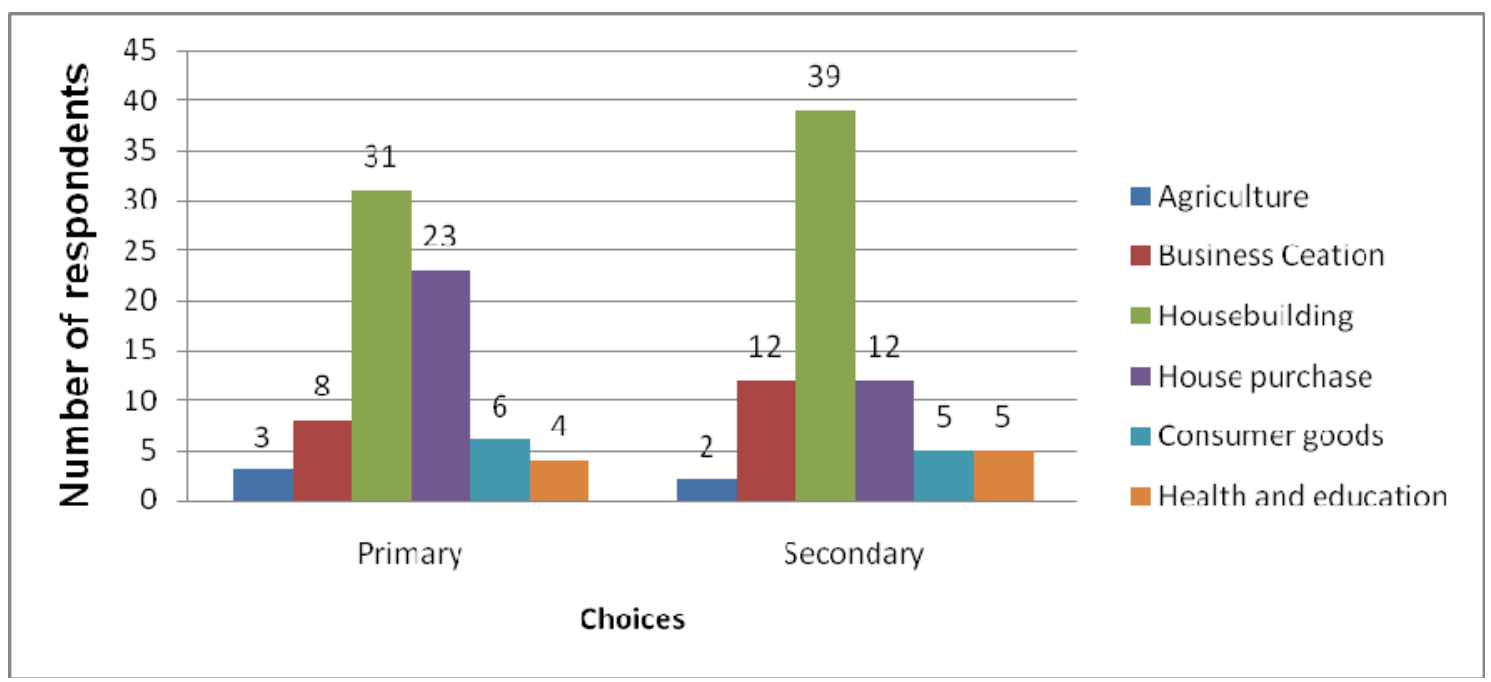

Fig. 6a Use preference of remitters.

Source: Derived from UK-Ghanaian residents survey (2011).

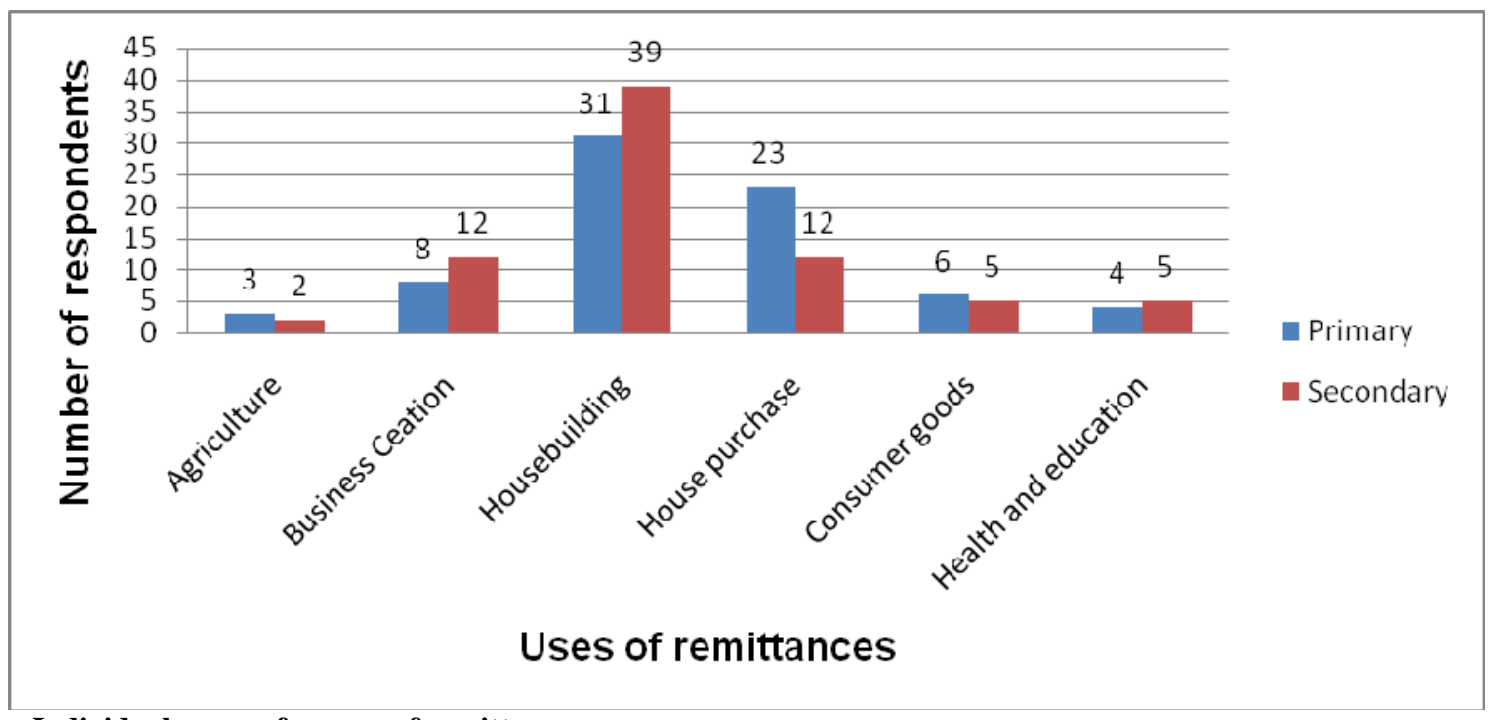

Fig. 6b Individual use preferences of remittances.

Source: Derived from UK-Ghanaian residents survey (2011). 
chose agricultural activity as neither primary nor secondary choice was that agriculture is often small-scale labour intensive family farming which does not generate need for sophisticated machinery.

\subsubsection{Business Creation}

According to the survey, business creation was indicated as primary reason for remittances by 11 percent and secondary reason by 16 percent of respondents. From personal observation, instances of significant business creation by returned migrants is common in Ghana. They often settle in bigger cities and towns and use their savings and new skills acquired abroad to create businesses including transport services, shops, restaurants and other service companies. Although returned migrants who create businesses may not be large in numbers, the fact that some of them are entrepreneurial and have international experience means that their impact on the local economy may be greater than their numbers alone suggest.

\subsubsection{House Building and House Purchase}

In common with the families of most migrants the world over [30, 31] a large proportions of remittances to Ghana are used for house building and purchase combined. According to the interviews portrayed in Fig. 6a, 54 respondents or 72 percent chose house building and house purchase as the primary reasons for remittances, and 51 respondents or 68 percent chose it as secondary reason. Activities here include using remittances for house repairs, buying plots, housing construction, outright purchase and/or mortgage repayment. Arguably, such expenditure enables the family members remaining back home (and returnee migrants) to enjoy the benefits of decent homes. Thus, Improvements in accommodation are by no means valuable in enhancing family wellbeing.

In a society such as Ghana where prestige and respect is commanded by material wealth, it is nearly impossible for one to be respected if one does not have a house to show. Thus, using savings and earnings from overseas to build a house is essential for migrants to feel respected in their communities. Building a large house is therefore not simply an ostentatious display by migrant households; it is also a prerequisite for meeting the basic human needs of self-respect and full integration into the society.

It is interesting to note that along with the inflow of cash into the economy and the boom in house construction remittances have acted as catalyst in the emergence of real estate development companies in Ghana. For instance a previous study by Karley [4] shows that around 65 percent of customers of major real estate development companies in Ghana are Ghanaians who live overseas and make payments through remittances. In addition, small construction teams in urban areas have emerged and engaged in construction of houses on incremental basis, that is, as and when funds become available presumably including those from remittances.

This observation is consistent with assertion by some respondents who indicated that they approach construction of their dream homes gradually through regularly sending money back home to Ghana. Obeng-Odoom [25] suggested that by this approach some Ghanaian residents in Sydney, Australia were able to build houses in Ghana within 3 to 6 years period. Whiles this has become a common and appreciable way to achieve the housing aspiration of most migrants; the downside is the emergence of urban sprawling as most have not been able to complete the houses as originally planned. Uncompleted houses are occupied by squatters and turned into slums (own observation).

Considering house purchase alone, about a third of respondents chose it as the primary reason for remittances and 16 percent chose it as secondary reason. A further analysis of the data shows that nearly all those who indicated house purchase as reasons for remittances were those who also indicated they were professionals. Unlike "other" migrants, it seems easier for "professionals" to obtain mortgage finance from providers in Ghana to purchase houses because they are able to provide verifiable evidence of their creditworthiness covering all the 5C's requirements 
[32] for mortgage provision. They tend to purchase houses in/and around the cities for example, Accra, Tema or Kumasi. This is a way for them to establish a similar lifestyle in Ghana as it was when they were abroad. Moreover, it ensures that their children get the best quality education.

6.2.3 Consumer Goods, Health and Education

Ten respondents or about 13 percent chose consumer goods, health and education combined as their primary and secondary reasons for sending money home. In terms of consumer goods remittances help family members back home to pay for everyday items such as soap, matches and clothes as well as contributions toward social events like marriage and funeral ceremonies. As alluded to earlier, instead of cash some remittances are sent in the form of durable modern consumer goods such as cars, Television sets, and other electronics and household effects.

According to migrants health and education expenses place a strain on household budgets and cannot be covered with income obtained through agriculture alone. So they send money to pay for medicines and other health services for children, parents, and other relatives, as well as paying school fees for children, siblings and other relatives. These are very important contributions toward family wellbeing and improvement in family social status. They contribute to lifting the standard of what counts as "respectable" for the family left behind. Arguably these contribute to fulfilment of the implicit contracts between the migrant and family left behind referred to in previous sections.

We now turn to discuss impact of the financial crisis on remittances and housing development process.

\section{The Impact of Recent Financial Crisis}

Essentially a financial crisis termed "credit crunch" is a sudden cut in the availability of credit or loans, including mortgages, credit cards and interbank lending as banks worry about a lack of liquidity. In situations where lenders don't want to lend, borrowers unable to borrow, builders unable to build and buyers unable to buy, economic activities could come to a standstill. This is a simple explanation of very complex set of issues which have been worsening and changing shape since the later part of 2007.

The recent global credit crunch began in the United States in 2007, when lenders' exposure to billions of dollars of bad debt mortgages began to spiral. Although the credit crunch started as a local phenomenon in a specialised housing market, it then expanded globally and into the mainstream of economies. Worries about the viability of sub-prime mortgage lending spread around the financial system and undermined the ability of banks and building societies to borrow sufficient resources or to feel confident about continuing lending to customers.

Across the globe during 2008 and 2009 (taken as the credit crunch period), there have been a chain reaction as it gradually became clear that in a globalised financial system bad risks had spread into many national and international banks with no clarity about where the risks lay. As a consequence of the loss of trust between and amongst banks, banks were reluctant to lend to borrowers and more importantly to themselves. The trend began in the property and construction industry which dramatically affected other economic entities. But the reluctance to lend to borrowers and at increasingly high interest rates spread more generally into firms and families [33]. Thus, the credit crunch affected firms and families in various ways as discussed presently.

\subsection{Reduced Income and Spending on Real Estate}

The problems, caused by the sub-prime crises in the US, have led to a widespread downturn in the global economy. Recent economic data, including unemployment figures from advanced economies, are not interesting reading; the US in particular experienced record levels of unemployment. In many advanced countries the squeeze on consumer as a consequence of the credit crunch, continue to ripple out 
into the wider economy with expected growth substantially lower than initial forecasts. For example, in the UK the 2.5 percent growth forecast for 2008 was actually just over $1 \%$, and the country experienced prolonged recession and unemployment rate which was around 8 percent at end of 2010. In any period of economic squeeze, especially with regard to credit, the likely effect is that the economy could run into recession as it occurred in the US, the UK and other European countries during the crisis; low consumption led to low street sales and low business profits, which in turn led to redundancies and unemployment. With unemployment comes, reduced household incomes, which affects household spending, including family remittances.

This study portrays that most migrants continued to remit similar proportion of their incomes even during the recent financial crises. Fig. 7a shows the total number of respondent's remittances before, during and after the credit crunch. All the seventy five respondents indicated they have remitted similar proportions before the crisis but this decreased by 13 percent to 65 respondents during the crisis and increased slightly by only 3 percent to 67 respondents after the crisis. This observation is somehow consistent with earlier analysis portrayed in Figs. 3a and 3b where the official statistics from Bank of Ghana showed shares of individual transfers to Ghana during and after the crisis are lower than before the crisis.
However, the proportion of respondents by type of work (portrayed in Fig. 7b) remitting before, during (77.5 percent) and after the crisis (95 percent) for professionals are lower than those in "other" group. This perhaps suggests “others” are much more resilient during the crisis compared to "professionals". As earlier alluded to, interviews with NTHC Properties shows a similar trend - reduction in their housing construction orders by 15 percent during the crisis period, and improved after 2010. This has far reaching implications for long term efforts to promote residential property development where remittances constitute a significant income to families for consumption and for that matter housing development.

\subsection{Declining Investment}

Borrowers, both retail and corporate are being squeezed by the global financial crisis, which spread as Banks suffered growing losses on mark downs on mortgage backed securities. Before the crisis it was much easier and cheaper in the UK and other advanced economies to obtain bank loans secured or unsecured on homes. These loans could be used for many purposes including financing property purchases abroad. But this has changed due to the decline in the housing market. Despite record cut in base interest rates in the US and by the Bank of England to 0.5 percent since March 2009, there is an upward pressure on market interest rates. Consumers saddled with

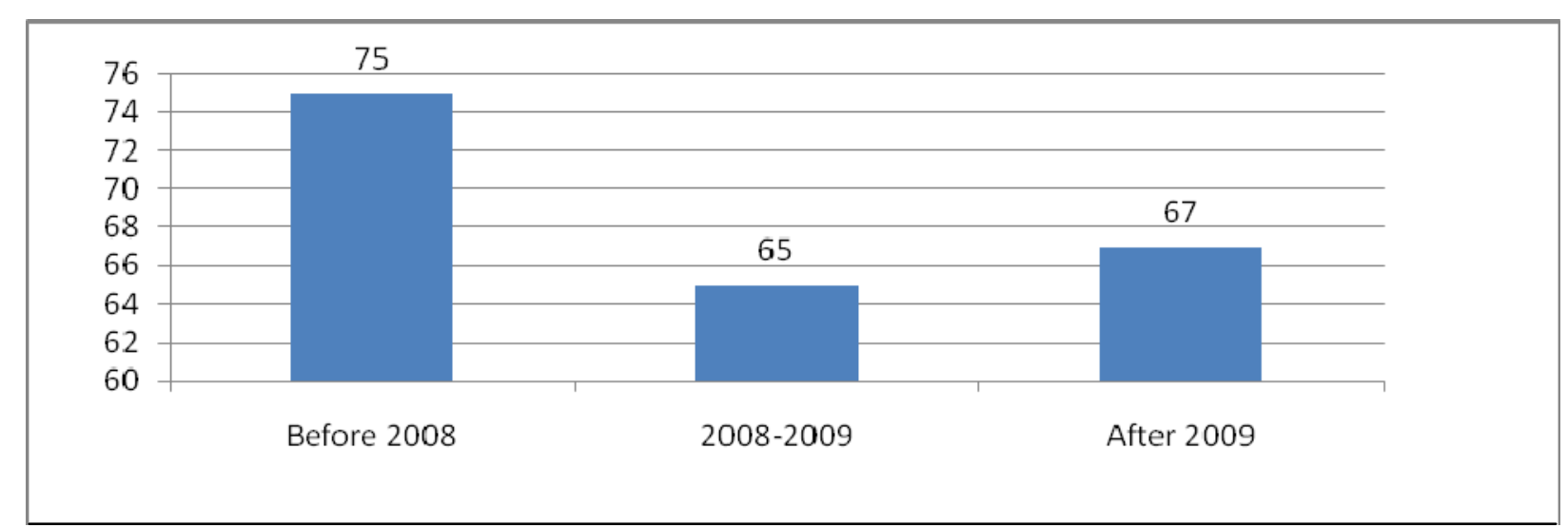

Fig. 7a Total numbers remitting before, during and after the credit crunch.

Source: Derived from UK-Ghanaian residents survey (2011). 


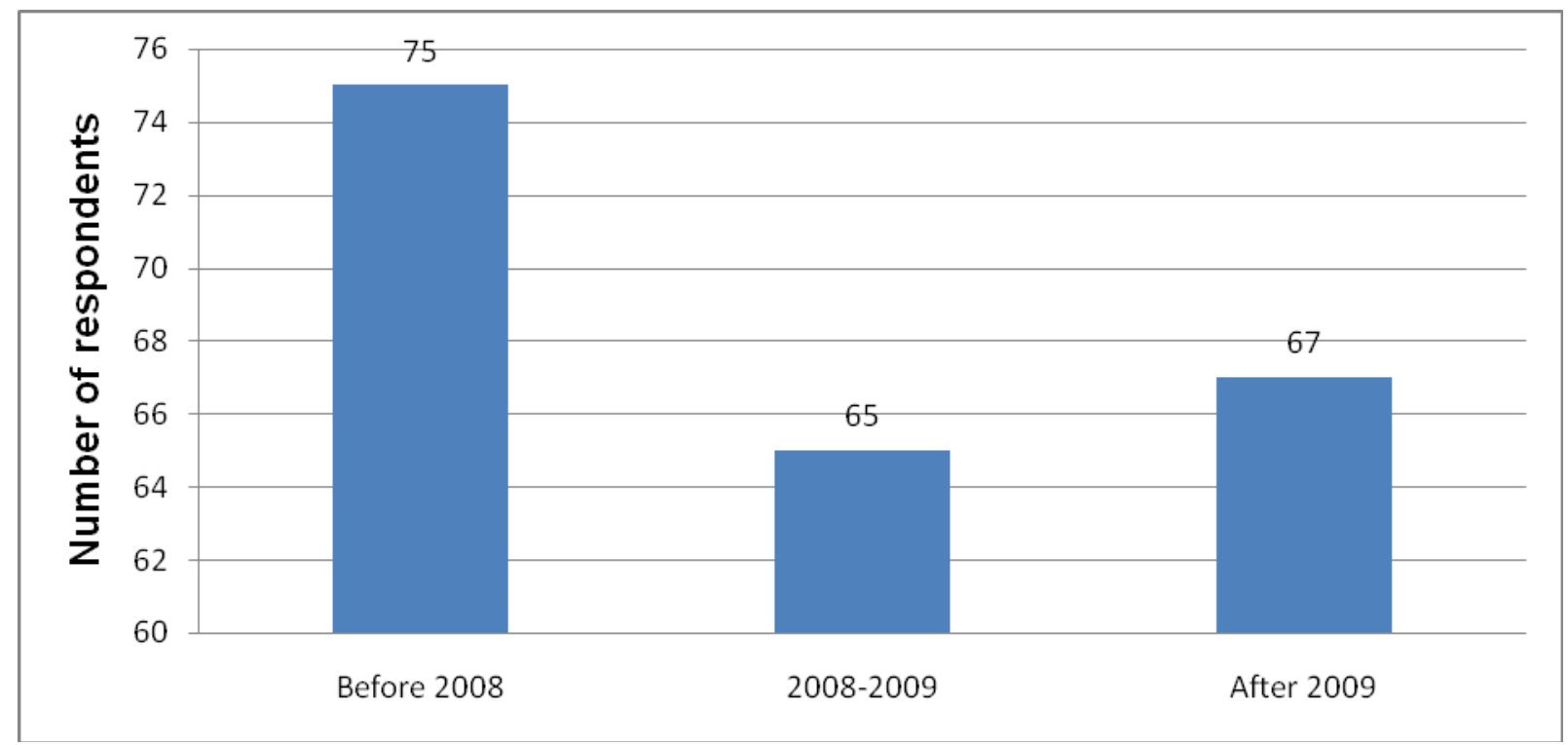

Fig. 7b Total numbers remitting before, during and after crises.

Source: Derived from UK-Ghanaian residents survey (2011).

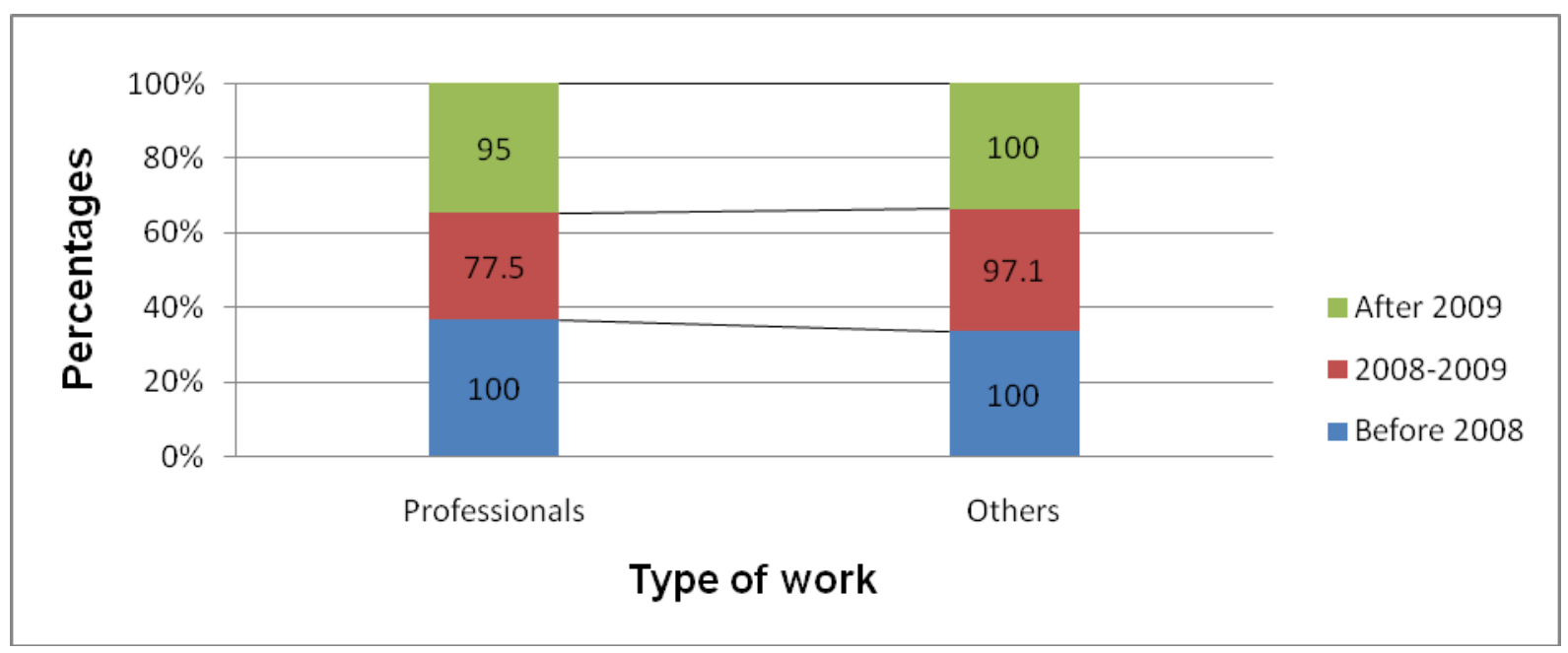

Fig. 7c: Proportions of migrant remittance by work type.

Source: Derived from UK-Ghanaian residents survey (2011).

record amounts of debt are no longer able to borrow against their homes as a consequence of falling housing market, and economic uncertainty. Investment and capital finance into businesses have been reduced. Bank lending has become tighter and high interest rates have led to fewer businesses expanding. People are also unwilling to invest in new businesses because of the recession.

Given that customers of residential property developers in Ghana are mainly Ghanaians living and working abroad, if developers experienced reduction in construction orders during the financial crisis period, it goes without saying (or at least), it could be said that their main customers (migrants) were perhaps also experiencing some sort of financial problems, most likely, including inability to secure loans. But this cannot be substantiated by the current study.

\subsection{Declining Housing Affordability}

Due to the global financial crisis, housing markets have assumed extreme levels of unaffordability as mortgage interest rates have risen and consumers burdened with huge debts. For example, in the UK consumers are burdened with more than $£ 1.5$ trillion of 
debt of which $£ 1.2$ trillion is mortgage debt [33]. The mortgage sector has been hit the hardest by the credit crunch. There is no easier mortgage credit where at the peak of the lending boom borrowers could self certify at more than 10 times earnings. Borrowers now face a much more draconian lending regime which hits all borrowers across the board and not just the subprime. Thus, the credit crunch exacerbate problem of affordable housing even with falling house prices.

This coupled with expensive mortgages and high deposits means most people (including those with intentions to send remittances to families or invest in properties abroad) are unable to afford properties home let alone remit or invest in properties abroad. Also, with property repossession increasing at a rapid rate, beating the record number set during the peak of the last housing bust, it is becoming virtually impossible to sustain borrowing against homes.

\subsection{Reduced Real Estate Development Activities}

Several changes have taken place in construction sector that affected the tenure and availability of jobs, purchases of land and completion of building schemes. Media reports show completed houses remain unsold even after price fell by 10 per cent in certain parts of the UK. As a result, many developments were in danger of being built only incrementally (i.e., when funds become available), and as a consequence, fewer numbers of homes were under construction. In the UK, it is estimated that 200 small-scale house builders failed since late 2007; more than 20,000 newly built private homes lied empty; and about 110,000 builders and craftspeople lost their jobs during the crisis period [33].

It could be argued that Ghana may be spared the direct effect of the global economic downturn outlined above. However, the same cannot be said of the indirect impact of the downturn. The argument goes as follows: Ghana's economy depends on commodities such as gold, cocoa, bauxite and others whose prices are relatively strong, compared to other periods of economic downturn, like that of the late 1990s. Because of the nature of Ghana's economic integration into the global system - including migrantion - if the global economic malaise continues, rising unemployment, low incomes and cutback on expenditure are likely to affect items such as remittances. Thus, it appears most likely the global financial crisis will have a significant indirect impact on the Ghanaian economy, and its housing industry.

\section{Concluding Remarks}

There is a growing interest in the role of remittances in the Ghanaian economy. This interest has been heightened by the recent increase in the flow of remittances to Ghana. This investigation shows that migrant remittances are useful sources of income to many Ghanaians, particularly in times of economic shock. The importance of migrant remittances is evidenced by the proliferation of money transfer institutions in the country (both formal and informal) and the rapid growth in the volume of such remittances. Migrant remittances are important sources of foreign exchange whose magnitude exceeds the amount of ODA to Ghana.

The survey shows that a significant proportion of remittances to Ghana are spent on consumptive investment activities, particularly house building and house purchases. The intent of the government to introduce remittance tax may be laudable in some respect. However, the economic feasibility of its intended policy is doubtful. First, this policy could serve as a disincentive to remit and consequently could derail the housing development process. Secondly, it is susceptible to failure because as the individual always try to maximise their utility and will therefore find alternative ways to remit home without using the official channels if government proceeds with its tax policy. It is therefore economically expedient, and politically wise for governments to concentrate efforts on policies that will direct more remittances through the formal channel instead of a policy that will divert 
remittances flow away from formal channels to the informal channel.

The recent financial crisis had considerable impact on urban economies, and impacted on the volume of remittances. Given the strong motivation to remit as in case of Ghana, migrants are less affected especially where they are engaged in "other" jobs (by definition not professionals). This should also be seen as very important sources of remittances especially during economic downturn.

Finally, official sources of information on destination and use of household remittances are important in estimating the impact of remittances on housing sector. But it has not been possible to obtain such information. These are some of the difficulties that characterise most developing countries. However, remittances are perceived as useful and formidable sources of achieving the housing aspiration of the populace of many growing urban households and the Ghana case provides useful lessons. Nevertheless, challenges and opportunities facing housing systems in various countries can be distinctive and thus policy initiatives to address them may not necessarily be directly transferable from one economy to another.

\section{References}

[1] World Bank, Regular Economic Report on Africa, Washington D.C., January 2006,

[2] World Bank, Outlook for Remittance Flows 2010-11, Migration and Development Brief Development Prospects Group, World bank April 23. (2010)

[3] R. Zoellick, The year in review 2008, Office of the World Bank Group, Washington D.C., 2009.

[4] N. K. Karley, Ghana residential property delivery constraints and affordability analysis, Housing Finance International Journal XXII (4) (2008) 22-29.

[5] Bank of Ghana (BoG), Statistical Bulletin, Accra, February 2008.

[6] E. Asare and C. Whitehead, Formal mortgage markets in Ghana: nature and implications, RICS Research Paper Series, Vol. 6, No. 13, Oct., 2006.

[7] N. K. Karley, An overview and the prospects of the Ghana real estate market, Report submitted to the RICS Education Trust, 2007.

[8] NTHC Properties, Discussions with Managing Director NTHC Properties, Jan. 2009.
[9] Ghana Real Estate Developers Association (GREDA), Discussions with President of GREDA, Jan. 2009.

[10] E. Addison, Remittances by migrant workers, Head of Research at the central bank, research paper presented at a migration seminar in Accra, July, 2004.

[11] A. Solimano, Remittances by emigrants: Issues and evidence, WIDER Discussion Paper No. 2003/89. WIDER/UNU, Helsinki, Finland, 2003.

[12] A. Solimano, Workers Remittances to the Andean Region: Mechanisms, Costs and Development Impact Mimeo ECLAC, 2003.

[13] O. Stark, The Migration of Labour. Cambridge, Massachusetts: Basil Blackwell, 1991.

[14] S. S. Russell, K. Jacobsen and W. D. Stanley, International Migration and Development in Sub-Saharan Africa, Vol. 2, Country Analyses. World Bank Discussion Papers No.102, The World Bank, Washington, D.C., 1990.

[15] J. E. Taylor, International migration and national development, Population Index 62 (2) (1996) 181-212.

[16] M. A. Diatta and N. Mbow, Releasing the development potential of return migration: The case of Senegal, International Migration 37 (1) (1999) 243-266.

[17] I. Koc and I. Onan, The impact of remittances of international migrants on the standard of Living of the Left-Behind Families in Turkey, in: Conference Proceedings of XXIV International Union for the Scientific Study of Population (IUSSP) General Conference, Salvador, Brazil, 18-24 Apr., 2001.

[18] S. Findley and S. Sow, From season to season: Agriculture, poverty, and migration in the Senegal River Valley, Mali, in: R. Appleyard (ed.), Emigration Dynamics in Developing Countries: Sub-Saharan Africa, London: Ashgate Publishing Ltd. 1998. pp. 69-144.

[19] I. Ahmed, Remittances and their economic impact in post-war Somaliland (2000), Disasters 24 (4) (2000) 380-389.

[20] K. P. Kannan and K. S. Hari, Kerala's Gulf connection: Emigration, remittances and their macroeconomic impact 1972-2000, Centre for Development Studies Working Paper 328, available online at: http://cds.edu/download_files/328.pdf.

[21] R. H. Adams and J. Page, Impact of international migration and remittances on poverty, Paper presented at the Department for International Development/World Bank Conference on Migrant Remittances, London, 9-10 Oct., 2003.

[22] C. Sander, Migrant remittances to developing countries: A scoping study, Paper Prepared for DFID, Bannock Consulting, June, 2003.

[23] J. C. Caldwell, African rural-urban migration: The movement to Ghana's towns, Canberra: Australian National University Press, 1969. 
[24] J. Litchfield and H. Waddington. (2003) "Migration and poverty in Ghana: Evidence from the Ghana living standards survey, University of Sussex, IDS Migration Working Paper Number 10, available online at: http://www.central.sussex.ac.uk/Units/SCMR/working_p ap.

[25] F. Obeng-Odoom, Urban real estate in Ghana: A study of housing-related remittances from Australia, Housing Studies 25 (3) (2010) 357-373.

[26] P. Acquah, Governor of the Bank of Ghana on remittances, Daily Graphic, Accra, 27 July, 2007.

[27] M. Blackwell and D. Seddon, Informal remittances from the UK: Values, flows and mechanisms, A Report to DFID by the Overseas Development Group, Norwich, Mar. 2004.

[28] R. Tiemoko, Understanding the Opportunities for and Challenges to Migrants' Investment in Côte d'Ivoire and Ghana, Africa Regional Sexuality Resource Centre, Lagos, 2004.
[29] A. de Brauw and S. Rozelle, Migration and household investment in rural China, Department of Economics working paper, Williams College, USA, 29 Dec., 2003.

[30] M. Lipton, Migration from rural areas in poor countries: The impact on rural productivity and income distribution, World Development 8 (1) (1980) 1-24.

[31] M. B. Mills, Contesting the margins of modernity: women, migration and consumption in Thailand, American Ethnologist 24 (1) (1997) 37-61.

[32] N. K. Karley, Alternative options to mortgages in Ghana, Housing Finance International XVII (2) (2002) 26-30.

[33] M. Parkinson, M. Ball and T. Key, The credit crunch and regeneration: Impact and implications, Independent Report to the Department of Communities and Local Government, 2009. 